\title{
Analysis of the Effect of Human Resources Investment and Economic Growth on Poverty Levels in the Island Province of Sumatra
}

\author{
Gika Apia ${ }^{1}$, Hasdi Aimon ${ }^{2}$ \\ 1Universitas Negeri Padang, Padang, Indonesia, $\square$ gika.apia94@gmail.com \\ ${ }^{2}$ Universitas Negeri Padang, Padang, Indonesia, $\bowtie$ s3dkpl@gmail.com
}

\begin{abstract}
Poverty is one of the fundamental problems which has always been the center of attention of the government in Indonesia. Poverty is a complex problem in areas in Indonesia because poverty is not only related to the problem of low levels of income and consumption, but also related to the low level of education, health and also about the powerless of the poor to participate in process development. This study aims to determine the effect of education investment, health investment and economic growth on poverty levels in the province of Sumatra. The analytical method used is Error Correction Model (ECM). The results of the study show that education investment has a negative and significant effect on the provincial poverty level on the island of Sumatra, while health investment has a proven negative and significant effect. then economic growth has a negative and significant effect on the provincial poverty level on the island of Sumatra. But in the short term the three independent variables do not have a significant effect on the provincial poverty level on the island of Sumatra.
\end{abstract}

Keywords: human resources investment, economic growth, poverty level

\section{Introduction}

Poverty is one of the fundamental problems which has always been the center of attention of the government in Indonesia. Poverty is a complex problem in areas in Indonesia because poverty is not only related to the problem of low levels of income and consumption, but also related to the low level of education, health and also about the powerlessness of the poor to participate in the development process. Poverty is defined as the inability to meet minimum living standards (Kuncoro, 2006). The basic needs that must be met include clothing, food, shelter, education and health. The problem of poverty is a complex problem and is also multidimensional. Therefore, efforts to reduce poverty must be carried out comprehensively, covering various aspects of life in an area.

Thus to overcome this problem of poverty, the government needs to know and understand in advance what factors influence the level of poverty, so that the steps in making policy are right and able to solve the root causes. According to (Kuncoro, 2006) there are three factors that cause poverty. One of the contributing factors to poverty is the low level of education. Education is a basic need for all people because educated people can at least have the ability to free themselves from poverty.

Education investment where this is seen from government spending in the education sector. research conducted by Raghbendra Jha, et al., (2001) The results of his study found that government spending on the education sector negatively affected poverty. Furthermore, the results of the research by Obayori et al. (2018) show that government spending in the education sector is negatively and significantly related to the level of poverty. Where the implications of this finding are that educated communities and adequate funding in the education sector will be able to reduce poverty in Nigeria.

Not only is the investment investment factor, but health investment is also a factor in reducing poverty. Health problems are things that are vulnerable to be faced by the poor, this is due to their economic limitations in an effort to improve themselves and fulfill their needs. According to (Kuncoro, 2006) Health is the core of welfare and education is the basic right to achieve a satisfying and valuable life. Health is also one of the factors in the success of development, especially to improve welfare. People who have good levels of health will have high levels of work productivity, high income levels, high levels of education, and a number of other positive things. 
Health investment will be far more meaningful to the poor when compared to the non-poor population because in the poor population the main asset is rough labor. The existence of inexpensive health facilities will greatly help to increase productivity and eventually increase income (Lanjouw et al, 2001). The results of a study conducted by Bakhtiari et al., (2010), namely an increase in the health sector will reduce poverty.

Another factor affecting the level of poverty is economic growth. Economic growth is a picture of the state of an economy from one sustainable area that can increase the prosperity of the community, where economic growth is characterized by the increasing number of goods and services produced by an area (Kuncoro, 2006). Economic growth can also be said to be the key to reducing poverty in a region. Increased economic growth in each province indicates that the government is able to improve the welfare of its people so that it can reduce poverty. Research conducted by Jonaidi, (2012) shows that economic growth is negatively correlated with Indonesia's poverty level. This means that the more economic growth in Indonesia, the lower Indonesia's poverty.

The phenomenon of variable investment in education, health investment and economic growth and poverty rates among provinces in Sumatra can be seen in table 1 below:

Table 1 Education Investment, Health Investment, Economic Growth and Provincial Poverty Rate on the island of Sumatra in 2016-2017

\begin{tabular}{|c|c|c|c|c|c|c|c|c|}
\hline \multirow[b]{2}{*}{ Province in Sumatra } & \multicolumn{4}{|c|}{ Year 2016} & \multicolumn{4}{|c|}{ Year 2017} \\
\hline & $\begin{array}{c}\text { Education Investment } \\
\text { (Billion) }\end{array}$ & $\begin{array}{c}\text { Health Investment } \\
\text { (Billion) }\end{array}$ & $\begin{array}{c}\text { Economic Growth } \\
(\%)\end{array}$ & $\begin{array}{c}\text { Poverty Level } \\
(\%)\end{array}$ & $\begin{array}{c}\text { Education Investment } \\
\text { (Billion) }\end{array}$ & $\begin{array}{c}\text { Health Investment } \\
\text { (Billion) }\end{array}$ & $\begin{array}{c}\text { Economic Growth } \\
(\%)\end{array}$ & $\begin{array}{c}\text { Poverty Level } \\
(\%)\end{array}$ \\
\hline Aceh & 1.143 & 1.052 & 3,30 & 16,51 & 1.153 & 1.065 & 4,19 & 15,99 \\
\hline Sumatera Utara & 1.692 & 1.526 & 5,18 & 10,30 & 1.701 & 1.529 & 5,12 & 9,30 \\
\hline Sematera Barat & 1.191 & 1.075 & 5,27 & 7,16 & 1.202 & 1.081 & 5,29 & 6,76 \\
\hline Riau & 1.559 & 1.390 & 2,23 & 7,72 & 1.578 & 1.396 & 2,71 & 7,46 \\
\hline Jambi & 1.053 & 985 & 4,37 & 8,41 & 1.062 & 990 & 4,64 & 7,93 \\
\hline Sumatera Selatan & 1.346 & 1.217 & 5,04 & 13,44 & 1.359 & 1.235 & 5,51 & 13,15 \\
\hline \begin{tabular}{|l|} 
Bengkulu \\
\end{tabular} & 990 & 891 & 5,29 & 17,09 & 1.013 & 899 & 4,99 & 15,64 \\
\hline Lampung & 1.190 & 1.116 & 5,15 & 13,89 & 1.204 & 1.120 & 5,17 & 13,07 \\
\hline Kep. Bangka Belitung & 999 & 932 & 4,11 & 5,07 & 1.031 & 935 & 4,51 & 5,33 \\
\hline Kepulauan Riau & 1.201 & 1.089 & 5,02 & 5,87 & 1.218 & 1.100 & 2,01 & 6,17 \\
\hline
\end{tabular}

Source : Central Bureu of Statistics (Processed 2019)

Table 1 above shows that education investment, investment and economic growth as well as poverty rates between provinces on the island of Sumatra during the period 2016-2017, the government continues to increase its investment amount, it can be seen that government spending in the education and health sectors shows an increasing number every year and the economic growth of each province also increases every year. This also has an impact on the poverty level of each province which has also experienced a decline. However, if examined carefully there are phenomena that are not in accordance with the existing theory. This can be seen in 2017 in the province of Aceh, the poverty rate is quite high at 15.99 percent. Even though education investment, health investment and economic growth have considerable value. in 2017 education investment amounted to IDR .1,153 billion, while the value of health investment was IDR.1,065 billion and economic growth reached 4.19 percent. Then in South Sumatra province also experienced the same thing where in 2017 the poverty rate was quite high at 13.15 percent. then in 2017 education investment amounted to IDR.1,359 billion, while the value of health investment amounted to IDR.1,235 billion and economic growth reached 5.51 percent.

Poverty

Poverty is defined as the inability to meet minimum living standards (Kuncoro, 2006). The basic needs that must be met include clothing, food, shelter, education and health. In addition, Woyanti (2013) defines poverty as a multidimensional problem characterized by the helplessness of individuals to fulfill basic life needs based on three standards of life problems: (1) lack of material that 
covers food, clothing, shelter, housing and health services ; (2) lack of social needs, including social exclusion, dependence and inability to participate in society and (3) insufficient income and wealth.

Investment in Human Resources

Investment in the field of human resources is a sacrifice of something that can be measured by the value of money in the hope of being able to obtain better income in the future (Hanapiah, 2011).

\section{Economic Growth}

Economic growth as a process of increasing the productive capacity in a continuous economy or continuously throughout time will result in increasing levels of income and national output (Todaro, 2006).

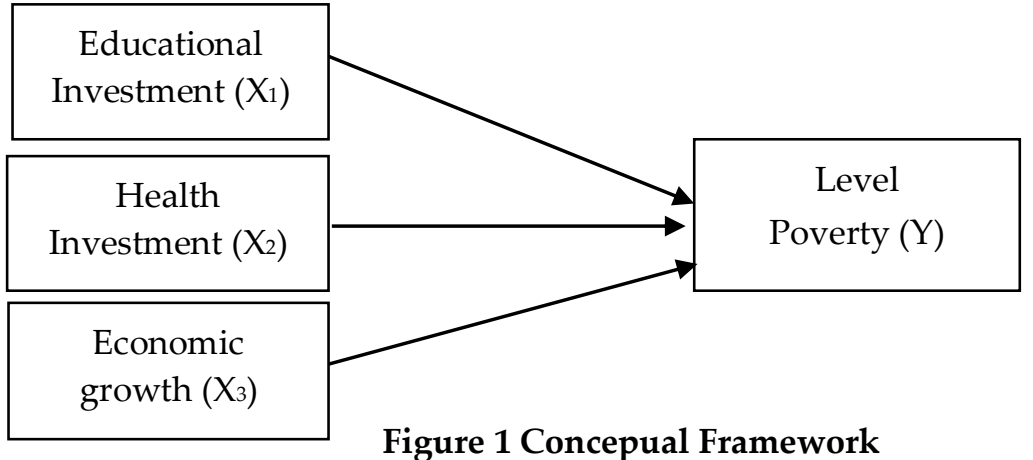

\section{Methods}

\section{Types of Research and Data Sources}

In this case, the research is descriptive and associative because it explains a phenomenon, events and events that are variable. Based on the data used in this study is quantitative, because the data is obtained in the form of numbers. While the data is used from the government agencies the Indonesian Central Bureau of Statistics (BPS) which is accessed through a website or internet site. Furthermore, based on the time of collection, the data used in this study uses the time series data from 2011-2017 provinces on the island of Sumatra with the amount of data (n) of $7 \times 10=70$.

\section{Operational Variable}

In this study, the operational limits used are as follows, a) Dependent Variable, Poverty, b) Independent variable, Educational Investment (X1), Health Investment (X2), Economic Growth (X3)

\section{Data Analysis Method}

multiple linear regression models.

$$
\begin{aligned}
& \mathrm{Y} \quad=\text { Poverty level } \\
& \beta_{0} \quad=\text { constant } \\
& \beta_{1}, \beta_{2,3} \quad=\text { regression coefficient } \\
& X_{1} \quad=\text { Education investment } \\
& \mathrm{X}_{2} \quad=\text { Health Investment } \\
& \mathrm{X}_{3} \quad=\text { Economic growth } \\
& \text { et } \quad=\text { Error Term }
\end{aligned}
$$

\section{ECM Model}

$$
\begin{aligned}
& \log \mathrm{Y} \quad=\text { Poverty level } \\
& \beta_{0} \quad=\text { constant } \\
& \beta_{1}, \beta_{2}, \beta_{3}=\text { regression coefficient } \\
& \log \left(X_{1} \quad=\right.\text { Education investment } \\
& \log X_{2} \quad=\text { Health Investment } \\
& \log X_{3} \quad=\text { Economic growth } \\
& \text { et } \quad=\text { Error Term }
\end{aligned}
$$




\section{Results and Discussion \\ Stationary Test}

The stationary test used is the unit root test developed by Phillip Peron (PP), better known as the root test of the Phillip Peron (PP) unit. Where if the Phillip-Peron (Phillip-Peron test statistic) value is a small probability of $\alpha=0.05$, then Ho is rejected or Ha is accepted which means the variable is stationary. The research variables can be stationary at the level, 1st difference, or 2nd difference. Furthermore, if the Phillip Peron (PP) statistical value is a large probability of $\alpha=0.05$, then Ho is accepted and $\mathrm{Ha}$ is rejected, which means that the variable is not stationary or contains unit root problems. Following are the results of stationarity testing.

Table 2 Stationary Test Results for Each Variable

\begin{tabular}{llc}
\hline \multicolumn{1}{c}{ Variable name } & \multicolumn{1}{c}{ level } & Probability value \\
\hline Proverty level $(\mathrm{Y})$ & $1^{\text {nd }}$ difference & 0.0000 \\
\hline Level of education $\left(\mathrm{X}_{1}\right)$ & $2^{\text {nd }}$ difference & 0.0000 \\
\hline Health investmen $\left(\mathrm{X}_{2}\right)$ & $2^{\text {nd }}$ difference & 0.0000 \\
\hline Economic Growth $\left(\mathrm{X}_{3}\right)$ & $2^{\text {nd }}$ difference & 0.0022 \\
\hline Source: results of data processing with Eviews 10 & \\
\hline
\end{tabular}

Table 1 above explains each stationary variable at a certain level, namely at 1 nd difference and 2 nd difference. From the table it can be seen that almost all stationary variables at the 2nd difference level, only one variable is stationary at the level of difference 1 . So for the next time, it is necessary to do a cointegration test.

\section{Cointegration Test}

Cointegration test is the next test after unit root test. Cointegration relationships indicate a longterm (equilibrium) relationship. The following are the results of the cointegration test.

\section{Table 3 Cointegration Test Results}

Null Hypothesis: Unit root (individual unit root process)

Series: RES

Date: 03/27/19 Time: 15:05

Sample: 20112017

Exogenous variables: None

Newey-West automatic bandwidth selection and Bartlett kernel

Total (balanced) observations: 60

Cross-sections included: 10

\begin{tabular}{lcc}
\hline \hline Method & Statistic & Prob. ${ }^{* *}$ \\
\hline PP - Fisher Chi-square & 54.2436 & 0.0001 \\
PP - Choi Z-stat & -4.43976 & 0.0000 \\
\hline \hline
\end{tabular}

From table 2 above it can be seen that in the RESIDUAL equation $1(-1)$, and the probability is small of $\alpha=0.05$. Therefore, each equation in this study is cointegrated or explains each other. In other words, although in this study the variables in each equation are stationary at different degrees but each variable is cointegrated, that is, there is a long-term relationship or balance between these variables. Thus the equation no longer contains the problem of false regression (spurious regretion) 


\section{Multiple Regression Test Result}

Table 4 Multiple Regression Test Results

Dependent Variable: LOG(Y)

Method: Panel Least Squares

Date: 03/27/19 Time: 13:54

Sample: 20112017

Periods included: 7

Cross-sections included: 10

Total panel (balanced) observations: 70

\begin{tabular}{crcrc}
\hline Variable & Coefficient & Std. Error & t-Statistic & Prob. \\
\hline C & 29.22183 & 2.483066 & 11.76845 & 0.0000 \\
\hline LOG $(X 1)$ & -0.120498 & 0.037531 & -3.210632 & 0.0020 \\
\hline LOG $($ X2) & -0.151739 & 0.030519 & -4.971887 & 0.0000 \\
\hline LOG $(X 3)$ & -1.202835 & 0.164465 & -7.313642 & 0.0000 \\
\hline R-squared & 0.645400 & Mean dependent var & 10.67455 \\
\hline Adjusted R-squared & 0.629282 & S.D. dependent var & 0.948441 \\
\hline S.E. of regression & 0.577474 & Akaike info criterion & 1.795138 \\
\hline Sum squared resid & 22.00942 & Schwarz criterion & 1.923624 \\
\hline Log likelihood & -58.82983 & Hannan-Quinn criter. & 1.846174 \\
\hline F-statistic & 40.04168 & Durbin-Watson stat & 0.076964 \\
\hline Prob(F-statistic) & 0.000000 & & \\
\hline
\end{tabular}

Source: Data Processing Results with Eviews 10

From the results above, the following results are obtained :

$$
\log \left(Y_{t}\right)=29.22-0.12 \log \left(X_{1 t}\right)-0.15\left(\log X_{2 t}\right)-1.20\left(\log X_{3 t}\right)+e_{t}
$$

Based on the results of the multiple regression equation above, it can be concluded that the constant value is 29.22. This means that if the education investment variable (X1), health investment (X2) and economic growth (X3), does not change or is considered zero, then the poverty rate that occurs is 29.22 percent.

The coefficient value of the educational investment variable of -0.12 means that if education investment (X1) experiences a 1 percent increase, the poverty rate will decrease by 0.12 percent with the assumption that the variable health investment (X2) and economic growth (X3) are considered constant. Educational investment with its measuring indicator is government spending in the education sector. This indicates that through education investment will be able to improve the quality of human resources shown by increasing knowledge and skills so that it will encourage an increase in one's productivity and ultimately someone who has high productivity will be able to obtain better welfare and avoid poverty.

The coefficient value of the health investment variable of -0.15 means that if health investment $(X 2)$ experiences a 1 percent increase, the poverty rate will decrease by 0.15 percent with the assumption that the education investment variable (X1) and economic growth (X3) are considered constant. Health investment with its measuring indicator is government expenditure in the health sector. Health affects poverty because health is a requirement to increase one's productivity. Someone who is in poor health will not do the job effectively. If someone is not effective at working then productivity is low. If productivity is low it means that income is also low. A person's low income will make the person difficult to fulfill their life needs so that the person can be trapped in poverty.

The coefficient value of the economic growth variable is -1.20. it means that if economic growth (X3) experiences a 1 percent increase, then the poverty rate will decrease by 1.20 percent with the assumption that the education investment variable (X1) and health investment (X2) are considered constant. The economic growth of a region is seen as an increase in GDP per capita in each region. 
The per capita GDP of a region can be used as a parameter or measure of the average level of income or welfare of the people in the area. If the GDP per capita of an area increases, then the economic growth of a region will experience an increase, this indicates that people's welfare will increase. By increasing people's welfare, this will reduce poverty in the region. Because economic growth is a condition of necessity in reducing poverty.

\section{Table 5 ECM Model Test Results}

Dependent Variable: DLOG(Y)

Method: Panel Least Squares

Date: 03/27/19 Time: 15:15

Sample (adjusted): 20132017

Periods included: 6

Cross-sections included: 10

Total panel (balanced) observations: 60

\begin{tabular}{crrrr}
\hline Variable & Coefficient & Std. Error & t-Statistic & Prob. \\
\hline C & 0.016399 & 0.014340 & 1.143583 & 0.2588 \\
\hline DLOG $(X 1)$ & -0.000264 & 0.005661 & -0.046630 & 0.9630 \\
\hline DLOG $(X 2)$ & -0.139359 & 0.332437 & -0.419204 & 0.6771 \\
\hline DLOG $(X 3)$ & -0.651658 & 0.423500 & -1.538745 & 0.1309 \\
\hline RES(-1) & $-2.43 E-06$ & $1.97 \mathrm{E}-06$ & -1.236485 & 0.2227 \\
\hline
\end{tabular}

Source: Data Processing Results with Eviews 10

From the above equation can be formulated as follows:

$$
\operatorname{Dlog}\left(Y_{t}\right)=0.016-0.00 \operatorname{Dlog}\left(X_{1 t}\right)-0.14 \operatorname{Dlog}\left(X_{2 t}\right)-0.65 \operatorname{Dlog}\left(X_{3 t}\right)-2.43 E C T
$$

Based on the results of management with the ECM model above, it can be seen that the correlation of all independent variables shows negative results. If you look at the probability value it can be analyzed that in the short term all variables cannot influence the level of poverty between provinces in Sumatra because it has a value that is not significant at the $0.05 \%$ confidence level.

\section{Conclusions}

From the results of testing education investment in the long term has a negative and significant influence on the level of poverty. While in the short term has a negative and not significant effect on the level of poverty. Educational investment with its measurement indicators is government expenditure in the education sector. Investment is a thing that cannot immediately affect output and also education investment requires a long time compared to investment with infrastructure investment. So in the short term education investment does not directly affect output.

From the results of testing the long-term health investment has a negative and significant influence on the level of poverty. While in the short term has a negative and not significant effect on the level of poverty. Health investment with its measurement indicators is government expenditure in the health sector. So in the short term, health investment has no direct effect on the level of poverty because health investments cannot directly increase a person's productivity. Someone who is in poor health cannot work. If someone does not work the productivity is low If productivity is low it means that income is also low. A person's low income will make the person difficult to fulfill their life needs so that the person can be trapped in poverty.

From the results of testing above economic growth measured by GRDP in the long run has a negative and significant influence on the level of poverty. This identifies that economic growth will cause an increase in income and increase the welfare of the people so the number of poor people will decrease. While in the short term has a negative and not significant influence on the level of poverty. It can be identified that the economic growth 
that occurs is more supported by the consumption sector from investment or capital formation, so that the quality of economic growth is not so good for reducing poverty. Another thing that happens to economic growth in the short term is where the economic growth that occurs is not followed by equal distribution of income, so that the poor do not get a significant increase.

\section{REFERENCES}

Bakhtiari et al., (2010) An empirical investigation of the effects of health and education on income distribution and poverty in Islamic countries. International Journal of Sosial Economics.

Jonaidi, A (2012). Analisis Pertumbuhan Ekonomi dan kemiskinan di Indonesia. Jurnal Kajian Ekonomi.

Lanjouw et al., (2001). Poverty, Education and Health in Indonesia: Who Benefits from Public Spending? December. Working Paper, World Bank, Washington, DC, (December).

Kuncoro, Murdrajat. 2006. "Ekonomi Pembangunan", Penerbit Salemba Empat, Jakarta

Obayori et al., (2018). Human Capital Investment and Poverty Reduction in Nigeria, 1 (February).

Raghbendra Jha, et al., (2001). An Emprical Analysis of the Impact of Public Expenditure on Education and Health on Poverty in Indian States. Ssrn, 998. https://doi.org/10.2139/ssrn.236888

Todaro, Michael P. dan Stephen C. Smith. 2006. Pembangunan Ekonomi (edisi kesembilan, jilid I). Jakarta : Erlangga

Woyanti, N. (2013). Pengaruh Pertumbuhan Ekonomi dan UMP Terhadap Kemiskinan di Jawa Tenagah Pra dan Pasca Desentralisasi Fiskal. Media Ekonomi Dan Manajemen, 28(2), 28-43. 